\title{
Změny, které se ne/konaly. Postkomunistická Evropa jako avantgarda společenského vývoje?
}

\section{"The changes that did (not) occur. The post-communist Europe as an avant-garde of the social development?"}

Václav Rameš / rames.vaclav@seznam.cz

Ústav českých dějin FF UK

\begin{abstract}
The paper focuses on the era after the democratic revolution of 1989, analysing the political agents' expectations about the nature of the future economic system. Describing the case of Czech-American economist Jaroslav Vanek and others, it shows that the contemporary debates included ambitious projects, which aimed at making Czechoslovakia a pioneer of new social orders, usually inspired by the ideas of so-called economic democracy. In conclusion, the paper compares these concepts with the actual development of the East European countries in the following decades, as it has been described in the conteporary researches.
\end{abstract}

\section{Keywords}

Post-communism; Privatization; Czechoslovakia; Participatory Enterprises; Geopolitics 


\section{Úvod}

Posledním velkým historickým mezníkem, který od sebe oddělil dvě výrazně odlišné etapy vývoje evropské společnosti, byly události demokratických revolucí na přelomu 80. a 90. let 20. století, během nichž se rozpadl tzv. východní blok. Konec komunistických diktatur znamenal pro východní Evropu začátek nové éry, která bývá zpravidla nazývána „liberální demokracií, případně, chceme-li charakterizovat nejen politický, ale i ekonomický systém, který se na troskách komunistických diktatur ustavil, „demokratickým kapitalismem“. Nesamozřjejmost druhého z těchto pojmů pro popis tehdejších událostí je však zřejmá už z letmého pohledu do historických pramenů, nebot neodpovídá jazyku a pojmům, v nichž svou současnou situaci pojímali tehdejší aktéři. Nejenže bychom na fotografiích z listopadu 1989 marně hledali transparent s nápisem „Za demokratický kapitalismus“, zřídkakdy bychom podobné sousloví nalezli i během prvních svobodných voleb o půl roku později v červnu 1990. Obraz vývoje po roce 1989 jako samozřejmého nasednutí do vagonů uhánějícího vlaku západního liberálního kapitalismu je tak při bližším pohledu neudržitelný, jakkoliv se na první pohled sám nabízí, a namísto něj se vnucuje otázka po tom, jaké představy měli tehdejší aktéři revoluční a těsně porevoluční doby ohledně budoucího ekonomického uspořádání své společnosti, jak vnímali přechod, který tato společnost prodělávala a s jakými vizemi a ambicemi do něj zasahovali.

Předkládaný přríspěvek vychází z toho, že přesvědčení o „konci komunismu“ bylo již během revoluce široce sdílené, chce se tedy zaměřovat na druhou stranu rovnice, tj. na definici kýženého stavu tak, jak jej aktéři sami popisovali. Z geopolitického hlediska bude pak úběžníkem našich úvah otázka, zda bychom nalezli v těchto postkomunistických debatách takové politické koncepty, které by přisuzovaly oblasti východní Evropy zásadní roli v budoucím vývoji našeho kontinentu. „Minulé budoucnosti“ tvoří zásadní složku jednání historických aktérů, nebot jejich vlastní činy interpretují jako součást příběhu, který jim samotným dává smysl, a orientují tak jejich jednání v současnosti. Podle Reinharta Kosellecka je „očekávání budoucnosti“ nerozlučně spjato se „zkušeností z minulosti“, tedy s interpretací té její části, která je pro aktéra v danou chvíli relevantní a nějak se ho dotýká; veřejně artikulovaná podoba tohoto očekávání a zkušenosti je pak často předmětem politického vyjednávání. ${ }^{1}$ Pro historický výzkum je objasnění toho, jakou budoucnost aktéři od svého jednání očekávali, důležité i k pochopení celkového ideového prostředí, v němž jednotlivci své názory formulovali a které mělo vliv i na způsob argumentace či na volbu klíčových pojmů, s nimiž ve své mluvě pracovali, snažíce se vymezit vůči svým názorovým odpůrcům. Po rozpadu autoritativního diskursu komunistické diktatury se v Československu uvolnil prostor pro veřejnou diskusi ve zcela nových podmínkách a předkládaný příspěvek má ambici ukázat, jak této nové situace aktéři využili k artikulaci svých představ o roli postkomunistických zemí v budoucí Evropě.

V ohnisku našeho zájmu budou stát především českoslovenští ekonomové, resp. ti, kteří se svými názory veřejně vystoupili a podle nichž znamenaly demokratické revolu-

1 Koselleck, Reinhart: Vergangene Zukunft. Zur Semantik geschichtlicher Zeiten. Frankfurt am Main 1989, zejména s. 349-359. 
ce ve východní Evropě příležitost $\mathrm{k}$ tomu, aby tento region využil mimořádné situace k převzetí iniciativy v celoevropském společenském vývoji, a pro něž tedy nebyla ekonomická transformace spojena s ideou přímého „návratu“ k existujícím západoevropským vzorům. Jakkoliv byly hospodářské procesy tohoto období již v době svého vzniku předmětem nevyčíslitelné řady odborných studií, porevoluční „minulé budoucnosti“, tedy očekávání budoucího vývoje a z nich plynoucích alternativních projektů ekonomické transformace, stojí spíše na okraji systematického odborného zájmu. Český čtenář má k dispozici především navzájem si konkurující výpovědi dobových pamětníků, které jsou začasto koncipovány jako vzájemné polemiky, a zejména velké množství politologických či ekonomických analýz, které hodnotí ekonomickou transformaci z hlediska její hospodářské úspěšnosti, resp. z hlediska procesu utváření institucí demokratického státu a systému politických stran. ${ }^{2}$ Existující historické analýzy se věnují zejména tématům vyrovnávání se s komunistickou minulostí, dějinám jednotlivých politických subjektů a institucí či národnostní problematice. ${ }^{3}$

Otázka soudobých transformačních alternativ v nich bývá pojednávána jen ve zkratce, pozornost je zpravidla věnována jen některým z účastníků tehdejších událostí (např. ekonomickému týmu pod místopředsedou vlády Č́R Františkem Vlasákem) a jiní jsou pomíjeni (např. autoři křestanských a komunistických koncepcí). Z tohoto hlediska může být jejich podrobnější analýza obohacením dosavadní historické reflexe porevolučního období a zároveň jejím propojením s reflexí ekonomickou, nebot tyto dvě odborné debaty zatím probíhají spíše paralelně vedle sebe. Za tímto účelem se vedle dobových i pozdějších textů, které po sobě zanechali četní pamětníci, nabízejí jako výnosný (a ne př́liš vytěžený) zdroj informací pro zkoumání „minulých budoucností“ i archivy dobových politických stran, $\mathrm{v}$ nichž lze nalézt materiály podávající svědectví o očekáváních a vizích nejen prominentních ekonomů, ale i stranických funkcionářu a řadových členů. Podrobnější analýza zahrnující i tyto aktéry by však přesahovala možnosti tohoto článku.

\section{Postkomunistická Evropa jako avantgarda zaměstnanecké participace? Vize Jaroslava Vaneka}

Podle amerického historika Jamese Krapfla se během Sametové revoluce v Československu požadavky demonstrujících dotýkaly především občansko-politických témat (dodržování

2 Ke konfliktním pamětnickým intepretacím viz např. Klaus, Václav: Chtěli jsme víc než supermarkety: kniha k 25. výroči pádu komunismu. Praha 2014. Klusoň, Václav: Úvahy post-transformační. Praha 2007. Zelený, Milan: Neučte se z vlastnich chyb: pohlednice z druhého břehu. Praha 2007. Ekonomické analýzy viz např. Myant, Martin: Vzestup a pád českého kapitalismu: ekonomický vývoj České republiky od roku 1989. Praha 2013. $\mathrm{Z}$ novějších politologických analýz viz např. Kopeček, Lubomír: Czech political institutions and the problems of parliamentary democracy. In: Czech Politics: From West to East and Back Again, Edd. S. Balík a kol. Berlin-Toronto 2017.

3 Viz např. Gjuričová, Adéla et al.: Rozděleni minulostí: vytuáreneni politických identit v České republice po roce 1989. Praha 2011; Suk, Jiří: Labyrintem revoluce. Aktéři, zápletky a křižovatky jedné politické krize. Praha 2003. Gjuričová, Adéla - Zahradníček, Tomáš: Náurat parlamentu. Češi a Slováci ve Federálním shromáždění 1989-1992. Praha 2018. Rychlík, Jan: Rozděleni Československa: 1989-1992. Praha 2012. 
lidských práv, demokratická správa), byly převážně nemateriální povahy a takové, které bychom mohli označit za ekonomické, byly protestujícími vznášeny v naprosté menšině. ${ }^{4}$ V prvních týdnech a měsících roku 1990 se však situace začala měnit. Vedle počínajících národnostních sporů se začala na pořad dne dostávat i otázka provedení ekonomické reformy, která během roku 1990 vykrystalizovala ve spor o provedení privatizace. ${ }^{5}$ Konsensus na tom, že v Československu privatizace proběhne, se ustavil během jara 1990 a prvním z vládních činitelů, kdo ji v oficiálním projevu označil jako jednu z hlavních součástí vládní ekonomické reformy, byl předseda federální vlády Marián Čalfa ve svém projevu o stavu federace, který přednesl ve Federálním shromáždění 27. února 1990. ${ }^{6}$ Situace, kdy se v Československu nacházela ve státním či státem přímo kontrolovaném (družstevním) vlastnictví naprostá většina existujícího majetku, činila z plánované privatizace sociální experiment olbřímích rozměrů, do té doby bezprecedentní, a dávala jejím budoucím architektům široké možnosti uplatnit při výběru těch, kdož budou shledáni vhodnými pro nabytí majetku, vlastní preference, resp. preference jejich voličů, kteří by vyslovili takovému plánu svou podporu. Architekt budoucí privatizace navíc mohl nabýt přesvědčení, že při konstruování nové vlastnické struktury společnosti je možné využít unikátní situace a nesnažit se vědomě kopírovat vzory západního demokratického kapitalismu, ale vyvarovat se toho, co by považoval za jeho nedostatky, a třeba se naopak pokusit „předběhnout“ ty jeho vývojové tendence, které považuje za progresivní.

Jedním z těch, kterým nechyběla ambice se o něco takového pokusit, byl americký ekonom československého původu Jaroslav Vanek, který se po listopadové revoluci na čas vrátil do Československa z emigrace ve Spojených státech. Vanek studoval ekonomii na Sorbonně a v Ženevě a od 60. let působil na Cornell University, kde se zabýval teorií a praxí podniků, v nichž se na řízení a vlastnictví podílejí jejich zaměstnanci. Díky svým pracím na toto téma se stal v akademickém světě uznávanou osobností s mezinárodním věhlasem, v porevolučním Československu však jeho jméno veřejnosti známé nebylo, nebot̉ se, na rozdíl od svých mladších kolegů, nijak nepodílel na reformách Pražského jara a až do roku 1990 nezasahoval do zdejšího politického vývoje.

Vanek se do Československa podíval poprvé po čtyřiceti letech v březnu 1989 na pozvání Ekonomického ústavu Československé akademie věd (EÚ ČSAV), a k této př́iležitosti sepsal studii, později vydanou pod názvem Střezte se klamu farizejů. ${ }^{7}$ Podle svých vlastních slov se v ní snaží čtenářům nabídnout „širokou analýzu sociálni a ekologické malátnosti kapitalistického Západu“ a varovat před ukvapeným přebíráním západních civilizačních vzorů, které prodělávají těžkou a vleklou krizi. Přestože psal tento text ještě v průběhu

4 Krapfl, James: Revolúcia s l’udskou tvárou. Bratislava 2009, s. 106-111.

5 Sám pojem privatizace lze v souladu s dobovým používáním chápat dvojím způsobem - jednak jako prodej státního majetku soukromým vlastníkům, jednak jako obecné „zesoukromění“ ekonomiky. V textu je pojem používán v prvním významu.

6 Viz stenografický záznam 24. společné schůze Sněmovny lidu a Sněmovny národů Federálního shromáždění ČSSR, http://www.psp.cz/eknih/1986fs/slsn/stenprot/024schuz/s024006.htm, citováno 19. 2. 2018.

7 Pozvání se týkalo konference o mikroekonomických modelech, organizované EÚ ČSAV v Liblicích v březnu 1989. Vanekův příspěvek byl později uveřejněn v knize Vanek, Jaroslav: Krize a reforma: východ a západ. Eseje o společenské ekonomice. Praha 1990, s. 8-28. 
roku 1988 a horizont jeho současnosti tvořily jen pokusy o přestavbu socialistických systémů, a nikoliv jejich naprostý rozklad, obrací se k tamním „východním a slovanským zemím“ s nadějí, že impuls k vytvoření „zdravého světa" a „plné demokracie“ může vzejít právě odtud a že na jeho počátku mohou stát soudobé Gorbačovovy reformy. ${ }^{8}$

Ve svém textu, který přivezl v březnu 1989 do Československa, Vanek formuloval své vize budoucnosti pouze $\mathrm{v}$ obecné rovině, přesnější představy o tom, jak by měly společenské reformy východního bloku probíhat, však popsal v další přednášce, kterou připravil v témže roce na pozvání od Ekonomického ústavu Akademie věd SSSR. Prvním krokem, který sovětským reformátorům Vanek doporučil, bylo rozbít centralizovanou strukturu hospodářských organizací a přenést rozhodovací pravomoci na větší množství samostatných jednotek, které by hospodařily co nejefektivněji. Základní jednotkou nové hospodářské soustavy měla být „samosprávná výrobni firma“, fungující na principu podnikové demokracie, v níž by zaměstnanci spolurozhodovali o všech podstatných otázkách (strategie firmy, rozdělení zisku atd.). Pracující, kteří už by nebyli redukováni jen na svou pracovní sílu jako na pouhé zboží, by jednali co nejhospodárněji a spravedlivě si mezi sebou rozdělovali výsledky své společné práce. Tento způsob organizace práce se dle Vaneka empiricky osvědčil jako hospodářsky nejefektivnější. ${ }^{9}$

Pád komunistických diktatur během následujících měsíců znamenal z hlediska těchto ambiciózních koncepcí radikálně novou situaci. To, co se ještě před několika měsíci mohlo jevit jako nerealistická iluze, bylo najednou proveditelné v dohledné budoucnosti. Jaroslav Vanek však zprvu po sametové revoluci neměl ambici se jakkoliv veřejně či politicky angažovat, přesvědčily jej až př́mluvy československých přátel, a vyprovokovalo ho i časopisecké interview z února $1990 \mathrm{~s}$ Václavem Klausem, kterého znal osobně ze 60. let jako svého hostujícího studenta. ${ }^{10}$ Právě konfrontace s Klausovými tezemi, které se od jara 1990 postupně stále více vyhraňovaly vůči všem „třetím cestám “ a alternativním společenským uspořádáním, přivedla Vaneka k podrobnějšímu vysvětlení svých plánů.

Rozpad „státního kapitalismu“, jak Vanek hospodářský systém komunistických diktatur nazývá, otevírá podle něj prostor pro širší uplatnění institucí „demokratického hospodárstvi “. Kritizuje Klausův výrok z února 1990, v němž československý ministr financí prohlašuje, že je potřeba "postavit všechny druhy vlastnictvi na stejný základ" - nikoliv však proto, že by s touto tezí principiálně nesouhlasil, ale proto, že Klaus podle něj opomenul dodat, že vedle státních a akciových firem je potřeba podpořit i „systémy demokratického hospodárstvi“". Jejich základem jsou výše zmíněné samosprávné podniky, v nichž má rozhodovací právo zaměstnanecký kolektiv skládající se z rovnoprávných členů disponujících vždy jedním hlasem a které Vanek doporučuje využít jako nástroj demonopolizace a decentralizace socialistických výrobních kolosů. $\mathrm{K}$ tomu je však potřeba přijmout patřičnou legislativu, která by jejich zakládání postavila na právní základ. ${ }^{11}$

8 Tamtéž, s. 25-27.

9 Tamtéž, s. 31-36.

10 Vanek, Jaroslav: Meditace o demokratických systémech a podnicích. Praha 1990, s. 2. Za zapůjčení textu upřímně děkuji paní Ing. Vlastě Hábové, CSc.

11 Tamtéž, s. 2-9. 
Československo by se nemělo dle Vaneka vydávat cestou západních států, kde se principy ekonomické demokracie musí uvádět do praxe zakládáním akciových společností, v nichž si zaměstnanci musí své podíly kupovat (tzv. Employee Stock Ownership Plan, známý pod zkratkou ESOP). Tuto cestu nepovažuje Vanek za vhodnou, nebot zbytečně odčerpává finance zaměstnanců, kteří se navíc dostávají do rizika, že v případě krachu jejich podniku přijdou i o své úspory, které do nákupu akcií vložili. Unikátní situace, kdy se v Československu demontuje státní vlastnictví, však umožňuje vytvořit demokratické podniky, aniž by si zaměstnanci museli svá podílnická práva kupovat. Západ je podle něj demokratický v politické sféře, ale autokratický ve sféře ekonomické, východ má nyní šanci setřást ze sebe jak autokracii politickou, tak ekonomickou. ${ }^{12}$ Československo se podle Vaneka může stát první plně demokratickou zemí na světě a zaujmout čelné místo na peletonu historického vývoje, který se pohybuje směrem „demokratizace a participace pracujicích“. ${ }^{13}$

\section{Z teorie do praxe: zaměstnanecké vlastnictví a samospráva v politických sporech 90 . let}

Vanekovo veřejné působení v Československu se nakonec omezilo na několik přednášek na téma ekonomické demokracie a samosprávných podniků, které pořádal během prvních porevolučních let, a na agitaci v podnicích na podporu samosprávných principů řízení. Nezastával žádnou politickou funkci ani se nepokoušel kandidovat do zastupitelských sborů a zůstal na pozici odborného kritika probíhající ekonomické transformace. Jeho ideje o ekonomické demokracii však rezonovaly na československé levici (přestože on sám s pravolevým rozdělením ve svých koncepcích vůbec nepracoval), která se začala aktivizovat na jaře 1990 v souvislosti s nadcházející novelizací zákona o státním podniku.

Zákon o státním podniku z roku (č. 88/1988 Sb.) byl jednou z hlavních změn přijatých během československé přestavby, která zaváděla do některých podniků tzv. podnikové rady a podniková shromáždění (\$28 - § 33) coby orgány socialistické samosprávy. Nejviditelnější pravomocí, kterou tyto orgány disponovaly, byla volba podnikového ředitele, kvůli čemuž se také ocitly po sametové revoluci pod palbou kritiky ze strany podnikových manažerů, podle nichž tento systém vyvolával v podnicích bezúčelný chaos a byl brzdou rozvoje. ${ }^{14}$ Podle zastánců myšlenek ekonomické demokracie se však mohly tyto samosprávné orgány stát, byṫ v pozměněné podobě, základem právě pro budoucí samosprávné firmy. Na těchto idejích vznikl krátce po listopadové revoluci Klub samosprávného lidového podnikání (KSLP), který si vytkl za cíl prosazovat principy ekonomické demokracie v Československu a pro jehož program byly silnou inspirací právě myšlenky

12 Tamtéž.

13 „Československo se může stát proni plně demokratickou zemi na světě“. In: Bulletin Klubu samosprávného lidového podnikání, červenec-srpen 1990, Praha 1990, s. 3, 8.

14 O privatizaci v našem hospodářstvi. Krok k vyšší výkonnosti. Hospodářské noviny, 6. 4 1990, s. 8-9. Též Ehrlich, Petr - Kaňa, Miroslav: Váhavost nemá budoucnost. Hospodářské noviny, 23. 3 1990, s. 7. 
Jaroslava Vaneka. ${ }^{15}$ KSLP byl jedním z mála politických subjektů, který se na jaře 1990 postavil za existenci podnikových samospráv. K podpoře demokratických principů v ekonomické sféře se přihlásily i některé zaměstnanecké kolektivy, např. pracovníci Škody Plzeň, kteří se v dopisu, zaslaném ministrům Klausovi, Dlouhému a místopředsedovi vlády Komárkovi, vyslovili pro převedení svých strojírenských závodů na samosprávný podnik. ${ }^{16}$ Václav Klaus jejich požadavky veřejně odmítl a vedle něj se proti podnikovým samosprávám postavila většina československých ekonomů, a tak finální verze nového zákona o podniku z dubna 1990 (zákon číslo 111/1990 Sb.) tyto podnikové orgány po jejich krátké existenci skutečně zrušila. ${ }^{17}$ KSLP se pak v následujících letech snažil prosazovat myšlenky podnikové samosprávy v rámci kuponové privatizace skrze založení vlastního investičního privatizačního fondu. ${ }^{18}$

Ti, kdož chtěli vytvořit z postkomunistického Československa vlajkovou lod' ekonomické demokracie, tak dostali první úder hned v první fázi porevolučního vývoje, ještě před samotným přijetím vládního Scénáře ekonomické reformy Federálním shromážděním v září 1990 (který je obvykle považován za počátek ekonomické transformace). Myšlenka, že šanci roku 1989 je třeba využít k překonání rozpadajícího se socialismu i nevýhod existujícího demokratického kapitalismu, však ze hry zrušením podnikových samospráv nezmizela. Vedle Vaneka se za ní postavil další do Československa se navrátivší emigrant, ekonom Milan Zelený. Ten představil na začátku května 1990 na Karlově univerzitě svůj program „Devatenáct tezí $k$ hospodárské obnově Československa“, který následně publikoval v několika novinách a časopisech, a dále je rozvíjel v sérii článků v Lidové demokracii, stranickém listu Československé strany lidové (ČSL). ${ }^{19}$

Zeleného koncepce rozlišuje mezi veřejným ( $\mathrm{tj}$. veřejně obchodovatelným) a soukromým vlastnictvím, přičemž veřejné vlastnictví, vyskytující se ve formě tradiční akciové společnosti, považuje za evolučně překonanou formu hospodářské organizace..$^{20}$ Pokud není vlastník akcií zároveň zaměstnancem podniku, má tendence prosazovat pouze krátkodobé investiční cíle a není se svou firmou natolik spojen jako někdo, kdo v ní pracuje a má přitom podíl na jejím zisku. Pro Zeleného je mnohem perspektivnější formou vlastnictví soukromé, v němž jsou majiteli podniku převážně a často i výlučně zaměstnanci a jejich akcie nejsou dostupné a směnitelné na burze. Takový systém by podle něj měl

$15 \mathrm{~K}$ činnosti KSLP viz např. Ekonomická demokracie. Teorie a praxe, KSLP - Česká společnost pro zaměstnaneckou participaci. Praha 2016.

16 Dopis ze Škodovky. Hospodářské noviny, 2. 3 1990, s. 14.

17 Klaus, Václav: Otevřená odpověd' Václava Klause na otevřený dopis ze Škodovky. Lidové noviny, 10. 31990, s. 3. Srov. Vlasák, František: Samospráva se zatím nikde neosvědčila. Hospodářské noviny, 23. 3 1990, s. 5.

18 Krtková, Eva: Pokus o tvorbu samosprávného podniku z iniciativy investičního (privatizačního) fondu. In: Otázky hospodářské samosprávy. Almanach KSLP. Praha 1996, s. 49-53.

19 Konference o trhu. Hospodářské noviny, 18. 5 1990, s. 14. Články později vyšly knižně, viz Zelený, Milan: Neučte se z vlastnich chyb: pohlednice z druhého břehu, Praha 2007, http://milanzeleny.com/cs-CZ/stranky/1/-/0/215/neucte-se-z-vlastnich-chyb>, citováno 14. 9. 2018. Všechny další citace pochází z tohoto vydání.

20 Pojem „veřejné vlastnictvi““ (public ownership) se používá také jako synonymum pro „státní vlastnictvi“", takto však Milan Zelený s tímto pojmem nepracuje. 
odstranit konflikt mezi vlastníky a zaměstnanci a vést $\mathrm{k}$ dlouhodobému zájmu majitelů-zaměstnanců o prosperitu podniku. ${ }^{21}$

V západní Evropě a v USA dochází podle Zeleného k podobnému přechodu od veřejného k soukromému vlastnictví, zejména formou zmiňovaných programů ESOP. Zelený se však odvolává i na domácí tradice a dává za př́klad systémy zaměstnaneckého podílnictví, jaké praktikoval ve svých závodech Tomáš Bata, a způsob řízení uplatňovaný v agrokombinátu Slušovice. ${ }^{22}$ Klíčem k úspěšné transformaci je podle něj správně provedená privatizace, která se v současnosti ukázala jako „jeden z nejrevolučnějších vynálezů v nedávné historii ekonomické politiky " musí jít ovšem o privatizaci do vlastnictví soukromého, nikoliv veřejného. Rozprodání akcií státních podniků mezi širokou populaci považuje za zbytečný mezičlánek, „poněkud opožděnou a dnes již převážně zbytečnou poklonu veřejnému vlastnictvi“, jejich takřka bezplatnou distribuci formou investičních kuponů pak dokonce za „ponižujici rozpoutáni divokého západu“.23

Československo mělo podle Zeleného unikátní šanci přeskočit „prostřední“ fázi veřejného vlastnictví a učinit ze svých zaměstnanců a manažerů podnikatele, namísto toho, aby se nacházeli v postavení pouhé pracovní síly v „námezdni republice“, kde by pracovali pro zisky svých anonymních akcionářů ${ }^{24}$ Cesta zaměstnaneckého vlastnictví pro něj byla spojená i se silným étosem: je nástrojem ekonomické demokracie, která postupně začíná doplňovat demokracii politickou a dává dřívějším zaměstnancům větší zodpovědnost za vlastní osudy i důstojnost. Navíc je podle Zeleného třeba zabránit tomu, aby v budoucnu převážná většina československých pracujících disponovala jen možností prodávat svou pracovní sílu, nebot její hodnota se bude stále zmenšovat. „Práce prestává být dominantním faktorem, hodnota kapitálu roste, cena práce klesá. Za těchto podmínek nesmí být lhostejné kdo je vlastnikem kapitálu“, napsal v srpnu $1991 \mathrm{v}$ argumentaci proti tezi, že cílem privatizace je pouze najít prvního vlastníka (at jím je kdokoliv), kterou naopak zastával Václav Klaus. ${ }^{25} \mathrm{~S}$ ním se Zelený dostal do ostrého sporu poté, co Klaus v novinách autoritativně odmítl myšlenku zaměstnaneckého vlastnictví s tím, že „v ekonomické vědě jde o vyř̌šenou otázku “, což Zelený označil za odbornou ignoranci. ${ }^{26}$ Během následné vzájemné výměny invektiv Klaus poukázal na fakt, že „nějaký neznámý pan profesor Zelený piše už $i$ do Rudého práva“, což mu adresát oplatil bohatým výčtem své zahraniční odborné činnosti, se kterou se ta Klausva nedala srovnat. ${ }^{27}$

21 Zelený, Milan: Využijme zuláštnich a neopakovatelných podminek. Státní > soukromé. Hospodářské noviny, 15. 8. 1990, s. 10 .

22 Bata, Tomáš: Knowledge in Action. Amsterdam - Oxford - Washington - Tokyo 1992. Předmluva Milan Zelený, s. V - IX. Srov. též Zelený Milan: Fenomén Slušovice. In: Neučte se z vlastních chyb, s. 24.

23 Zelený, M.: Využijme zuláštních.... Týž: Neni to jedno! In: Neučte se z vlastních chyb, s. 82.

24 Zelený, M.: Scénář: námezdni hospodářství, chudoba a stagnace? In: Neučte se z vlastních chyb, s. 84.

25 Tamtéž.

26 Reforma nepotřebuje korekturu. Hospodářské noviny, 21. 10 1991, s. 9. V dříve citovaném dopise zaměstnancům Škody Plzeň z března 1990 se však Klaus ještě vyjadřuje o zaměstnaneckém vlastnictví jako o možné cestě, kterou by se reforma mohla ubírat. Reakce Zeleného viz Neni to jedno! In: Neučte se z vlastních chyb, s. 82.

27 Zelený, Milan: Nežít ve lži, In: Neučte se z vlastních chyb, s. 115. 
Federální ministr financí svým popíchnutím poukázal na fakt, že Zelenému se nedostávalo zdaleka takové politické podpory, jako jemu, v té době již předsedovi nejsilnější české politické strany. Série článků, které publikoval v Lidové demokracii, otevírala možnost, že by ČSL převzala Zeleného návrhy do svého ekonomického programu. ČSL se skutečně už během volební kampaně na jaře 1990 prezentovala jako podporovatel „lidových“ (v jejich pojetí zaměstnaneckých) akcií, během hlasování o klíčových zákonech však podpořila koncepci federálního ministra financí a nakonec v ní převládl ve vztahu ke Klausově koncepci pragmatický postoj, vyjádřený slovy z dokumentu programové komise „pozitiva prevažuji nad negativy“ a „celkové směřrováni lze hodnotit kladně“. ${ }^{28}$ Zelený následně veřejně vystupoval společně s dalšími Klausovými protivníky, jako byl poslanec Miloš Zeman nebo profesor ekonomie z VŠE Milan Matějka, nikdo z nich však neměl za sebou vlivnou politickou sílu, která by mohla uvést jeho koncepce do praxe. ${ }^{29} \mathrm{Tu}$ postrádalo i jeho pozdější angažmá ve stínové vládě Liberálně sociální unie, která se ve volbách v létě 1992 nedostala do parlamentu. ${ }^{30}$

Idea Československa jako pionýra zaměstnaneckých podniků tak nevzbudila širší zájem veřejnosti, přestože na její podporu vystupovali i další odborníci. Jedním z nich byl i pozdější ministr financí Zemanovy vlády Pavel Mertlík. Ten, ještě před oficiálním představením Zeleného tezí, publikoval v dubnu 1990 článek v Hospodářských novinách, v němž spojuje koncepce zaměstnaneckého vlastnictví s vizemi transformace celého politického systému ve „stát občanské samosprávy, budovaný zdola, v němž si lid vládne skutečně sám “. ${ }^{31}$ Mertlíkova vize se zakládá na představě o ekonomice samosprávných podniků, spravovaných svými zaměstnanci, a na „podřizeni ekonomiky společenské kontrole“, která bude všem občanů dávat možnost podílet se na společenském majetku, a poskytne jim tak materiální podmínky pro realizaci jejich svobody. Mertlík se vymezuje proti tradičnímu liberalismu, který spojuje svobodu se soukromým vlastnictvím, protože taková svoboda ze sebe automaticky vylučuje ty, kdož nevlastní nic. Podmínkou svobody tudíž podle Mertlíka není soukromé vlastnictví, ale „vlastnictvi pro všechny “, tedy v nějaké formě samosprávného podniku. Na rozdíl od Vaneka nezavrhuje systémy ESOP jako možnou cestu pro československou transformaci, naopak tvrdí, že oproti přesvědčení mnohých neexistuje žádný empirický důkaz, který by dokazoval jejich principiální neefektivnost v porovnání s jinými typy podniků. Postindustriální éra, která se ohlašuje v USA, se podle Mertlíka odehraje ve znamení demokratizace a decentralizace jak politické, tak ekonomické sféry života, a listopadová revoluce otevřela Československu unikátní šanci zapojit se do tohoto civilizačního trendu, směřujícího k společnosti 21. století.

28 Archiv Československé strany lidové (AČSL), fond Předsednictvo ústředního výboru, Závěry programové komise (nedatováno, pravděpodobně léto 1991), s. 3.

29 Ekonomická reforma na rozcestí. Hospodářské noviny, 29. 8 1991, s. 2.

30 Viz Kopeček, Lubomír: Miloš Zeman - př́běh talentovaného pragmatika: Intelektuál válči s intelektuály. Brno 2017, s. 97.

31 Mertlík, Pavel: Promarníme svoji šanci? Hospodářské noviny, 13. 4 1990, s. 4. 


\section{Česká radikální levice a vize ekonomické demokracie}

Vanek, Zelený ani Mertlík se během prvních klíčových let po revoluci nestali politiky a zůstali na pozici odborníků, jejichž myšlenkám se nedostalo potřebného přeložení do jazyka, který by mohl oslovit masy, a dodat jim tak potřebnou veřejnou podporu. Nalezli bychom však podobně ambiciózní vize o možné progresivní roli postkomunistické Evropy v programech tehdejších politických stran a hnutî́? Nejsilnější Občanské fórum se na přelomu let 1990 a 1991 stalo platformou pro liberálně konzervativní pravici, která naopak přišla s programem vybudování společnosti podle již existujících západních vzorů, a následnické subjekty ODS a OH tento program (přes ideologické rozdíly mezi oběma uskupeními) převzaly. Až do podzimu 1990 v rámci OF existovala i uskupení otevřeně se hlásící k budování nových forem socialismu, jako byla např. Obroda nebo Levá alternativa, které však byly v listopadu 1990 po tlaku ze strany nově zvoleného předsedy Václava Klause z OF vyloučeny. ${ }^{32}$

Největší opoziční stranou zůstávala KSČM, v níž se po olomouckém sjezdu v září 1990 dostalo do vedení reformisticky naladěné křídlo okolo filmového režiséra Jiř́ího Svobody, které si vytklo za cíl zbavit stranu totalitního dědictví a přetvořit ji v demokratickou radikálně levicovou stranu. Po chaotickém období první poloviny roku 1990, kdy nad komunistickou stranou visela hrozba zákazu existence a kdy věnovala velkou část svých sil vlastní reorganizaci, kterou si vynutil přechod na federální strukturu (vytvoření KSČM jako republikové paralely ke KSS), se teprve na podzim 1990 mohla pořádně věnovat definování nového politického programu. $\mathrm{V}$ něm se přihlásila $\mathrm{k}$ budování „demokratického socialismu“ a „sociálně a ekologicky regulovaného tržního hospodářstvi“, směrem $\mathrm{k}$ veřejnosti pak strana vystupovala jako reprezentant těch, na které dopadnou očekávané negativní důsledky hospodářské reformy. ${ }^{33} \mathrm{Na}$ olomouckém sjezdu strany na podzim 1990 zaznívala od delegátů podpora samosprávným koncepcím v podobě, v jaké se objevovaly v prostředí KSLP, a jeho zástupkyně Vlasta Hábová, která na sjezdu vystoupila, KSLP i program klubu představila. ${ }^{34}$ Návrh privatizačního zákona, který vypracovala v následujících měsících skupina komunistických poslanců, i samotný projekt „demokratické ekonomické reformy “, který přijal ÚV KSČM v únoru 1991 jako svůj výchozí hospodářský program, tak v mnohém vychází z podobných idejí jako koncepty KSLP, s nimiž je pojily i osobní kontakty jejich autorů..$^{35}$

Jakkoliv si komunisté v té době byli vědomi, že období koncepčních debat na vládní úrovni v prvních dvou třetinách roku 1990 jim proteklo mezi prsty, a že tedy jejich možnosti ovlivnit směřování Československa jsou po prvním sjezdu KSČM dosti omezené,

32 Archiv Koordinačního centra Občanského fóra (AKCOF), Ústav pro soudobě dějiny, karton č. 1 „Rada, kolegium, kruh, kmen“, Zápis z rady OF 30. 10 1990, s. 1.

33 Archiv KSČM (AKSČM), fond I. sjezd KSČM, Obsahové dokumenty I. sjezdu KSČM, s. 1-8.

34 Tamtéž, Stenografický záznam sjezdu, s. 94.

35 Srov. Návrh ústavniho zákona o prevodu státniho majetku do fondi̊ hospodářské obnovy a podmínkách jeho privatizace, snèmouni tisk č. 382 Federálního shromážděni ČSFR (VI. volebni obdobi), https://www.psp.cz/ eknih/1990fs/tisky/t0382_00.htm, citováno 2. 9. 2018. Srov. s AKSČM, fond Zasedání ÚV KSČM 1990 1992 (ZUV), zasedání 16. 2 1991, Demokratická ekonomická reforma - návrh koncepce. 
neopouštělo je přesvědčení, že brzy může nastat čas, kdy se naskytne nová šance k uplatnění jejich vlastních představ o budoucím vývoji. ${ }^{36}$ Okolnost, že komunistický program ekonomické reformy byl poprvé předložen ústřednímu výboru jen pár dnů před schválením zákona o velké privatizaci ve federálním shromáždění, okomentoval jeho autor Z Hába poznámkou, že krach vládní hospodářské koncepce je tak jako tak nevyhnutelný a do několika měsíců či let vznikne poptávka po koncepci nové. ${ }^{37}$ Cesta k demokratickému socialismu, kterou nabízí KSČM, byla podle předsedy Svobody šancí nejen pro Československo, ale pro celou moderní společnost: „Připomeňme si i slova Jana Pavla II., který v encyklice Centesimus Annus vyslovil naději, že právě z naši části Evropy by mohly vzejit nové civilizačni a kulturni impulsy, včetně nového řěseni vztahu kapitálu a práce, které by současný evropský proces posunuly z roviny pouhého připojeni nebo podrobeni na úroveň plnohodnotné integrace, z niž by pro Evropu mohla vzejit nová kvalita společenských vztahư “. 38

To, že se předseda KSČM odvolával na autoritu papeže, bylo nejenom reformním signálem směrem ke konzervativním proudům ve vlastní straně, které se po prvotním porevolučním šoku začaly opět ozývat, ale i odkazem na morální a hodnotovou přeměnu společnosti, o níž encyklika mluví především. ${ }^{39}$ "Konči doba politických útvarů založených na abstraktnich principech. Misto toho se rýsuje preměna všech státních útvarů na základě politiky zájmů, organickou cestou zdola“, dodával Svoboda a připojil se tak k těm, kdož viděli potenciál osvobozené střední a východní Evropy v rozvíjení demokratických principů a jejich přenášení i do oblastí, v nichž se až doposud neuplatňovaly. ${ }^{40}$

K představám o samosprávné ekonomice se u komunistů pojily i vize tzv. „integrálniho občanstvi “. ${ }^{41}$ Jeho základním prvkem mělo být přebudování statických společenských struktur do podoby sítí, které by umožnily „podchytit jakoukoliv systém obohacujíci iniciativu“ a které by poskytovaly možnost pro odformalizování vztahů mezi lidmi a odstranění jejich vzájemného odcizení. Nové občanství mělo vytvořit nový typ společenského subjektu, překonávající dosavadní izolaci individuí a poskytující prostor principo̊m solidarity a samosprávy, které by zahrnovaly i uznání práv doposud vykořistovaných skupin obyvatelstva a vedly i k přehodnocení vztahu člověka k jeho životnímu prostředí. ${ }^{42}$

Výše popsané změny měly být podle příslušných programových návrhů KSČM nejlépe uskutečnitelné právě na území bývalého východního bloku, pro který zároveň představují jedinou alternativu samostatného vývoje, nebot v případě, že by této šance postkomunistické země nevyužily, dostanou se do „neokoloniálni závislosti“ na západním světě. „Osudy

36 K reflexi opožděného nástupu levice v ČSFR srov. např. Lipavský, Jan: Komu překáží samospráva? In: Mosty 8, 1990, s. 7.

37 AKSČM, fond ZUV, Stenozáznam 4. zasedání ÚV 23. 3. 1991, s. 13.

38 Zpráva výkonného výboru ÚV KSČM přednesená Jiř́m Svobodou na 6. zasedáni ÚV KSČM. Viz Současná situace ve společnosti a úkoly strany. Haló noviny, 10.9 1991, s. 3

39 Text encykliky, zejména bod $\check{c}$. 26, http://www.kebrle.cz/katdocs/soc_enc/CentesimusAnnus.htm, citováno 2. 9. 2018.

40 Současná situace ve společnosti a úkoly strany. Haló noviny, 10. 9 1991, s. 3.

41 Návrh volebniho programu KSČM pro volby 1992 (prèdběžné teze), s. 6-8. AKSČM, fond ZUV, zasedání 7. 9. 1991.

42 Jakou politiku? (pracovni materiál, autoři J. Svoboda a M. Ransdorf), s. 4. AKSČM, fond ZUV, zasedání 23. 3. 1991. 
lidí na celé planetě jsou závislé na schopnosti vymknout se neosobnímu diktátu mezinárodních finančnich center a nalézat alternativy, " píše se v návrhu volebního programu KSČM pro rok $1992 .{ }^{43}$ O potřebě sjednotit levicové síly střední a východní Evropy a zabránit jejímu upadnutí do pozice periferie západu hovořili i marxistický intelektuál Zbyněk Fišer (alias Egon Bondy) a jeho kolega Ivan Sviták - ten dokonce myšlenky ekonomické demokracie označil za samotný „smysl českých dějin“..44

Vliv nekonformních levicových intelektuálů na směřování strany byl však malý a i Svobodovo reformistické vedení, které poskytovalo v rámci KSČM velký prostor různým názorovým platformám od eurokomunistů přes ekosocialisty až po konzervativní leninisty, se postupem času dostávalo do stále větší defenzivy. ${ }^{45}$ Ambiciózní projekt přeměny KSČM v radikálně levicovou stranu vyznávající liberální občanské hodnoty se do velké míry omezoval jen na špičky strany a narážel čím dál více na odpor konzervativního členstva, které podobné civilizační vize odmítalo a dávalo přednost mnohem uměřenějšímu konzervativismu, prostému vizí o ekologizaci společnosti a přeměně společenských struktur v sítě a soustředícímu se na hájení sociálních jistot těch, kteří se cítili novou situací nejvíce ohroženi. ${ }^{46}$ Nástup konzervativního vedení strany po Svobodově rezignaci v červnu 1993 znamenal konec vstřícného pohybu KSČM směrem ke středu a zajistil jí stabilní místo v politické izolaci, v níž se strana nacházela už od listopadové revoluce.

\section{Česká pravice - postkomunistická Evropa a nová vlna liberalismu}

V průběhu let 1991 a 1992 tak postupně získávalo v Československé veřejnosti největší podporu přesvědčení, že by se naopak neměla pokoušet vynalézat nové formy společenského uspořádání, ał už politického či ekonomického, ale převzít již existující vzory západních demokracií. Nositelem tohoto programu byla zejména na jaře 1991 vzniklá ODS, která se $\mathrm{k}$ „osvědčeným principưm, [...] na nichž je založena západni civilizace“ přihlásila už ve svém prvním programovém prohlášení v dubnu $1991 .{ }^{47}$ C̆asto veřejně prezentovaná příchylnost ODS k britské konzervativní straně (a zejména její předsedkyni Margareth Thatcher) a odkazy na pojmy jako „přirozenost“, „civilizovanost“ a „tradice“ v jejích programech se přímo vymezovaly vưči snahám o hledání nových řešení starých problémů. I liberálně konzervativní zastánci volného trhu však reflektovali nečekaný rozpad sovětského impéria jako příležitost k tomu, aby východní Evropa převzala iniciativu a inspirovala západní demokracie, které jí přitom měly sloužit za vzor. Zkušenost postko-

43 Návrh volebního programu KSČM pro volby 1992 (předběžné teze), s. 6. AKSČM, fond ZUV, zasedání 7. 9. 1991.

44 Moučková, Miroslava: Má levicové hnutí budoucnost? Mosty1, 1991, s. 8-9.

45 Doposud nejpodrobnější přehled o ideovém vývoji uvnitř KSČM v raných 90. letech podává Fiala, Petr Holzer, Jan - Mareš, Miroslav - Pšeja, Pavel: Komunismus v České republice. Vývojové, systémové a ideové aspekty působení KSČM a dalších komunistických organizací v české politice. Brno 1999.

46 Zásady volebního programu KSČM 1992 (návrh). AKSČM, fond ZUV, zasedání 14. 121991.

47 Cesta $k$ prosperitě. Programové prohlášení Občanské demokratické strany schválené na ustavujícím kongresu v Olomouci 21. 4 1991, s. 5. Archiv Hlavní kanceláře ODS (AHKODS), 
munistických zemí se měla uplatnit zejména při hledání budoucnosti evropské integrace, která vstoupila po Maastrichtských smlouvách v únoru 1992 do nové fáze.

Představitelé občanských demokratů kritizovali již na počátku 90. let federalistické tendence v západní Evropě jako přiliš byrokratické, potlačující přirozenou existenci národních států a v konečném důsledku zatěžující volný trh množstvím zbytečných regulací a příkazů. Perspektiva vstupu Československa do čerstvě se ustavující Evropské unie se tak pro ně spojovala s otázkou, jaká role by měla postkomunistické zemi v novém společenství připadnout, resp. do jakého společenství by vlastně měla chtít vstoupit. Václav Klaus v této souvislosti prohlásil na ustavujícím sjezdu ODS, že podporuje vstup „do Evropy demokratické, založené na volném trhu zboži, práce, kapitálu, myšlenek. Tedy nikoliv Evropy byrokratické, která by vytuárenenim spousty centrálnich orgánů chtěla opakovat některé chyby naší vlastni minulosti“.48

Předseda strany tak načrtl možnou roli postkomunistické země v Evropě coby nositele důsledně liberálních myšlenek, které sice v západní Evropě vznikly, zároveň se však tamtéž dostaly do krize, a východní Evropané, poučeni svou čerstvou historickou zkušeností, je mohou svým západním sousedům opět připomenout. Místopředseda strany Miroslav Macek v této souvislosti podotkl, že „východoevropské země maji bohužel často oprávněný dojem, že socialistické myšlenky se $k$ nim v jistém smyslu vraceji ze západu "a hovoří o „pražské výzvě , která by se měla zformovat v zájmu opětovného prosazení liberálních principů do evropského společenství. To je podle něj poznamenáno protekcionismem starých zemí Evropského společenství, které namísto prosazování volného trhu hájí své národní ekonomické zájmy a z tohoto důvodu mají i obavy z přijetí nových východních demokracií mezi sebe. ${ }^{49}$

Revoluce ve východní Evropě, která podle Klause začala vítězstvím britských konzervativců ve volbách v roce 1979, by tak mohla stát na počátku nové historické etapy pro celou Evropu. ${ }^{50}$ Macek uvažuje o progresivní úloze, kterou by bývalé komunistické státy mohly sehrát při vytváření zcela nového typu mezinárodní struktury, která „by nevycházela ze starého mechanistického a autokratického pojeti svèta, jakkoliv vylepšeného", ale z nových kooperačních principů, inspirovaných např. „přirozenými biosystémy “ nebo „moderním průmyslovým podnikánim “. Hierarchická struktura národních států a jejich nadnárodních seskupení by se tak měla rozpustit, stejně jako se v té době rozpouštěly tradiční firemní hierarchie ve velkých podnicích a byly nahrazovány pružnějšími způsoby organizace.

\section{Závěr}

Měli-li bychom si tedy na závěr odpovědět na svrchu položenou otázku, zda doboví aktéři vnímali revoluci roku 1989 jako př́ležitost pro to, aby region východní Evropy přinesl do světa novou kvalitu společenského uspořádání, pak odpověd' zní nepochybně ano.

48 Bulletin ODS, mimořádné kongresové čislo, 20. dubna 1991, s. 6. AHKODS

49 Macek, Miroslav: Cesta do Evropy - ale do jaké? Sobotní telegraf, 18. 7 1991, s. 1.

50 Rovná, Lenka: Premiérka jejiho veličenstva. Praha 1991, s. 11 (předmluva V. Klause). Obdobné myšlenky viz též Klaus, Václav: Síla idejí, Literární noviny. 25. 4 1991, s. 1. 
Myšlenka, že proběhnuvše revoluce budou znamenat zásadní převrat ve způsobu, jakým je organizována lidská práce, zdaleka nebyla doménou marginálních anarchistických skupin, jako byla Levá alternativa, ale v určité podobě je nalézáme i u nekomunistických autorů, jakým je např. Jaroslav Vanek či Milan Zelený. Celá řada těch, kteř́i vyjadřovali své představy o budoucím uspořádání porevoluční společnosti, pak vnímala situaci Československa jako jedinečnou a zejména od nadcházejícího procesu privatizace si slibovala možnost přesunu východní Evropy z periferie do centra světového dění. Mezi ně lze počítat i vládnoucí liberální konzervativce, v jejichž představách se východoevropské země měly uplatnit v prostředí co nejvolnější mezinárodní konkurence, za jejíž vytvoření se měly v nově vznikající Evropské unii zasazovat.

Ekonom Martin Myant hovoří ve své analýze postkomunistických transformací o specifickém typu tzv. „českého kapitalismu“, který u nás vznikl v 90. letech a který lze těžko přiřadit $\mathrm{k}$ nějakému již existujícímu vzoru. ${ }^{51}$ Podle Myanta se jednalo o politický projekt, vyznačující se specifickým mixem liberálního a sociálně demokratického přístupu, konec tohoto českého kapitalismu pak Myant klade ke konci tisíciletí, kdy se jeho specifika rozpouští v modelu evropského kapitalismu v souvislosti se vstupem ČR do EU. Česká republika by tak podle tohoto výkladu do Evropy po svém vstupu nepřinesla liberalizační vítr, jak očekával Miroslav Macek, ale spíše by sama přejala vzorec uspořádání západoevropských zemí. Mackovým očekáváním by tak nedostála, stejně jako očekávání těch, kteří v ní chtěli vidět zemi zaslíbenou zaměstnanecké participaci a ekonomické samosprávě. Rakouský historik Philipp Ther ve své nedávné syntéze poukazuje na fakt, že státy východní Evropy po svém vstupu do EU přeci jen tvář unie změnily, když začaly v nultých letech jako první v Evropě aplikovat neoliberální ekonomické reformy, jako např. systém rovné daně z př́ijmu. ${ }^{52}$ Vlna těchto opatření přešla v Evropě od východu na západ a byly to právě postkomunistické země, kdo v ní měl klíčovou iniciativu - jakkoliv k tomu nakonec došlo jiným způsobem, než si představovali ti, kdož uvažovali o jejich vyhlídkách těsně po sametové revoluci.

\section{"The changes that did (not) occur. The post-communist Europe as an avant-garde of the social development?"}

Inspired by Koselleck's analysis of Futures Past, the paper focuses on the political imagination of some Czech economists and on their projects of future development of Czechoslovak post-communist society. The unique situation in the Eastern Europe of the early 1990's opened the door for the ambitious visions of social transformation, such as the ones promoted by Jaroslav Vanek, a Czech-American economist who had elaborated in the previous decades a project of economic transformation, based on the ideas of participatory economy. Although Vanek did not overstep his position of expert and did not become directly politically engaged, his ideas resonated on the

51 Myant, Martin: The Czech Republic: from ,Czech' Capitalism to ,European 'Capitalism. In: Varieties of Capitalism in Post-communist Countries. Edd. M. Myant - D. Lane. Basingstoke 2007, s. 117. 
Czechoslovak left and were partly adopted even by the Communist party. According to those conceptions, the eastern European countries were supposed to establish a new social order, which was already being born in the West, without having to overcome the path-dependency of the liberal capitalism and would therefore become the pioneers of the new trends in the development of the modern society. Similar attitudes were not uncommon in the contemporary debates, as the examples of Milan Zelený or Pavel Mertlík show, although they did not eventually find sufficient political support. The People's party, which was favourable to Vanek's ideas because of their Christian ethos, preferred in the end the loyalty to the politics of Václav Klaus, and the Communists were politically isolated and could not affect the governmental policy. Nevertheless, as a brief analysis of the statements of the ODS leaders shows, the notions of eastern Europe's exceptionality were shared even by the liberal rightists, who saw its mission in countering the etatist and cryptosocialist tendencies of the contemporary Western governments. None of those visions eventually came true, but the eastern European countries significantly contributed to pushing through the neoliberal policies after their ascent to the EU, as the analysis of historian Philip Ther shows. 
